\title{
PETROLOGICAL AND GEOCHRONOLOGICAL ASPECTS OF THE PRECAMBRIAN MAFIC DYKE SWARM OF URUGUAY
}

\author{
J.Bossi $i^{1}$ \\ N.Campal ${ }^{1}$ \\ L.Civetta ${ }^{2}$ \\ G.Demarchi ${ }^{3}$ \\ V.A.V.Girardi $i^{4}$ \\ M.Mazzucchelli \\ E.M.Piccirillo ${ }^{3}$ \\ G.Rivalenti ${ }^{5}$ \\ S.Sinigoi ${ }^{3}$ \\ W.Teixeira ${ }^{4}$ \\ A.R.Fragoso-Cesar
}

The subparallel mafic dykes of the Florida-Durazno-S.José region (SW Uruguay) trend N60-80W and vary in thickness from 0.6 to $50 \mathrm{~m}$. They are part of the mafic dyke swarms intruding granitic-gneissic basement that were mapped by BOSSI et al. (1989), in an area approximately $200 \mathrm{~km}$ in length and $100 \mathrm{~km}$ in breadth. Plagioclase, augite, subcalcic augite (pigeonite) and opaques are the main components of the dykes. Orthopyroxene and olivine are very rare. Biotite and hornblende are secondary minerals. Quartz-feldspar intergrowths occur in the coarser grained dykes. The characteristic textures are subophitic and intersertal.

\footnotetext{
${ }^{1}$ Faculdad de Agronomia, Universidade de Montevideo, Uruguay,

${ }^{2}$ Dipartimento de Geofísica e Vulcanologia, Università di Napoli, Italy.

3 Istituto di Mineralogia e Petrografia, Università di Trieste, Italy.

4Instituto de Geociências, Universidade de São Paulo, Caixa Postal 20899, 01498 São Paulo, SP, Brazil.

5 Istituto di Mineralogia e Petrologia, Università di Módena, Italy.
} 
In accordance with geochemical studies, the mafic dykes were divided into two groups, named, respectively, the Northern (ND) and Southern (SD) dyke swarms. The ND swarm is made up of tholeilitic andesites, and the SD swarm is mainly composed of andesi-basalts (Fig. 1). The ND swarm ( $\mathrm{mg}=0.25-0.31$ ) is more evolved than the SD swarm $(\mathrm{mg}=0.40-0.56$ ) and is characterized by higher contents of $\mathrm{TiO}_{2}$ and incompatible elements (Figs. 2, 3).

ND and SD swarms show important differences in many incompatible element ratios: $\mathrm{P} / \mathrm{Zr}(\mathrm{SD}=3.7-5.4 ; \mathrm{ND}=5.4-7.8) ; \mathrm{Ti} / \mathrm{Zr}(\mathrm{SD}=35-49 ; \mathrm{ND}=49-72 ; \mathrm{Zr} / \mathrm{Ce}$ (SD = 3.8-4.6; ND = 3.2-3.8); $\mathrm{Zr} / \mathrm{Nd}(\mathrm{SD}=8.5-13.5 ; \mathrm{ND}=6.7-8.9) ; \mathrm{Zr} / \mathrm{Sm}(\mathrm{SD}=30-45 ; \mathrm{ND}=25-30) ; \mathrm{Zr} / \mathrm{Gd}(\mathrm{SD}=$ 29-37; ND = 24-29) (Fig. 4). These differences suggest different parent melts for both swarms. REE distributions for SD and ND swarms show very similar La/Yb ratios (5.9 and 5.6 respectively) which is compatible with a garnet peridotite mantle source that experienced about $10 \%$ melting.

Previous geochronological analyses (K/Ar method in whole-rock samples) indicated ages varying from 1.4 to $1.6 \mathrm{Ga}$ (GOMES RIFAS, 1988). A recent K-Ar determination carried out in biotites from granitic country rocks, which are in sharp contact with one of the dykes, yielded an age of $1,786 \pm 0,020 \mathrm{Ga}$.

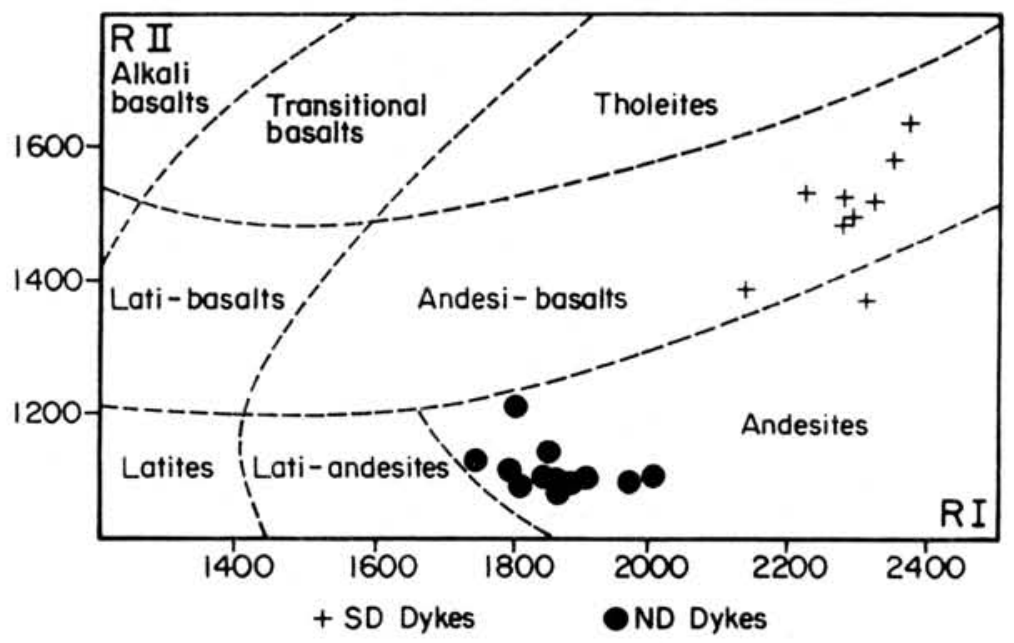

Figure 1 - Data from the dykes of Uruguay plotted on a $R_{1}-R_{\| \mid}$diagram. 

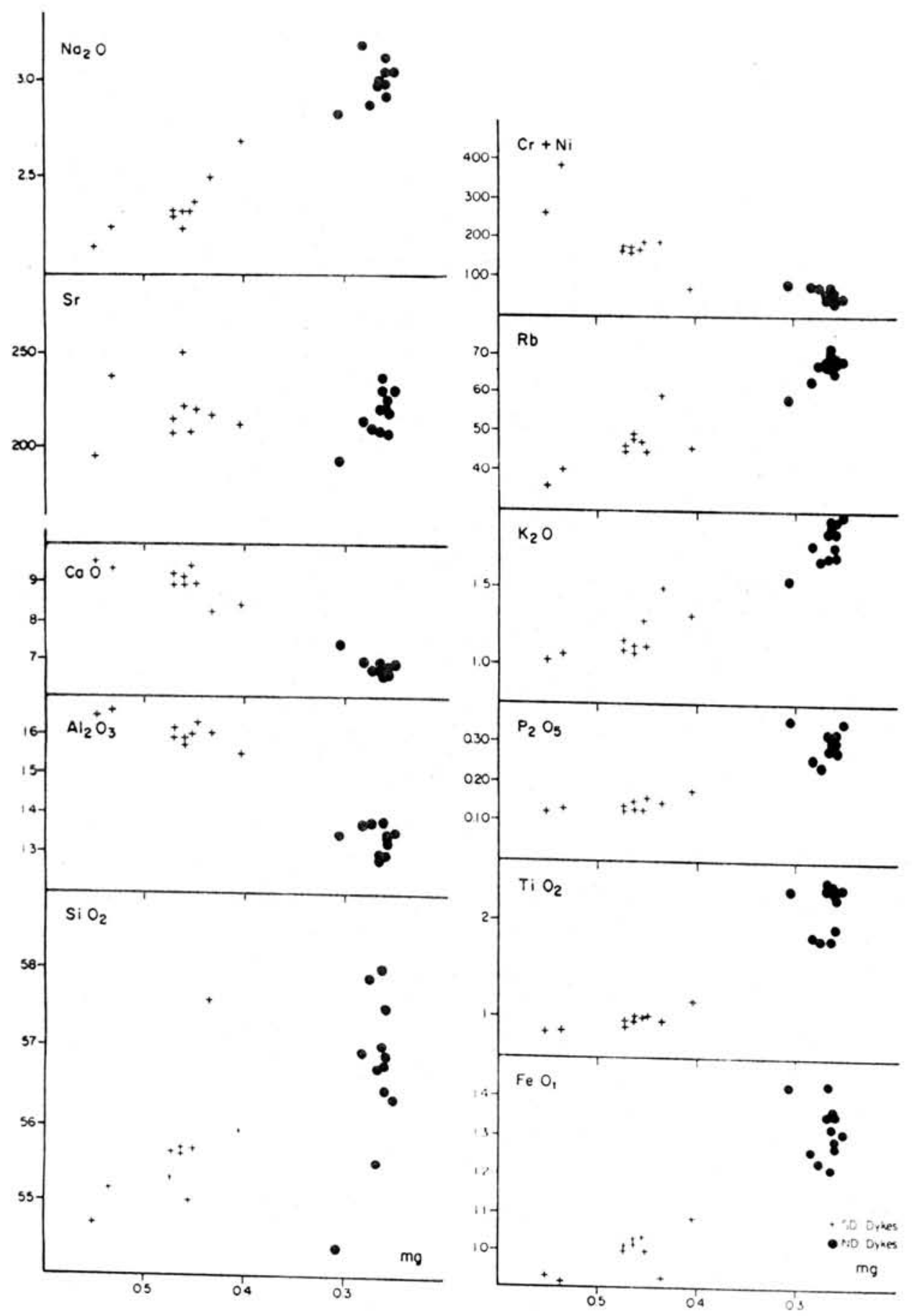

Figure 2 - $\mathrm{mg}$ versus $\mathrm{Na}_{2} \mathrm{O}, \mathrm{Sr}, \mathrm{CaO}, \mathrm{N}_{2} \mathrm{O}_{3^{\prime}} \mathrm{Cr}+\mathrm{Ni}, \mathrm{Rb}, \mathrm{K}_{2} \mathrm{O}, \mathrm{P}_{2} \mathrm{O}_{5}, \mathrm{TiO}_{2}$ and $\mathrm{FeO}_{\mathrm{T}}$. 


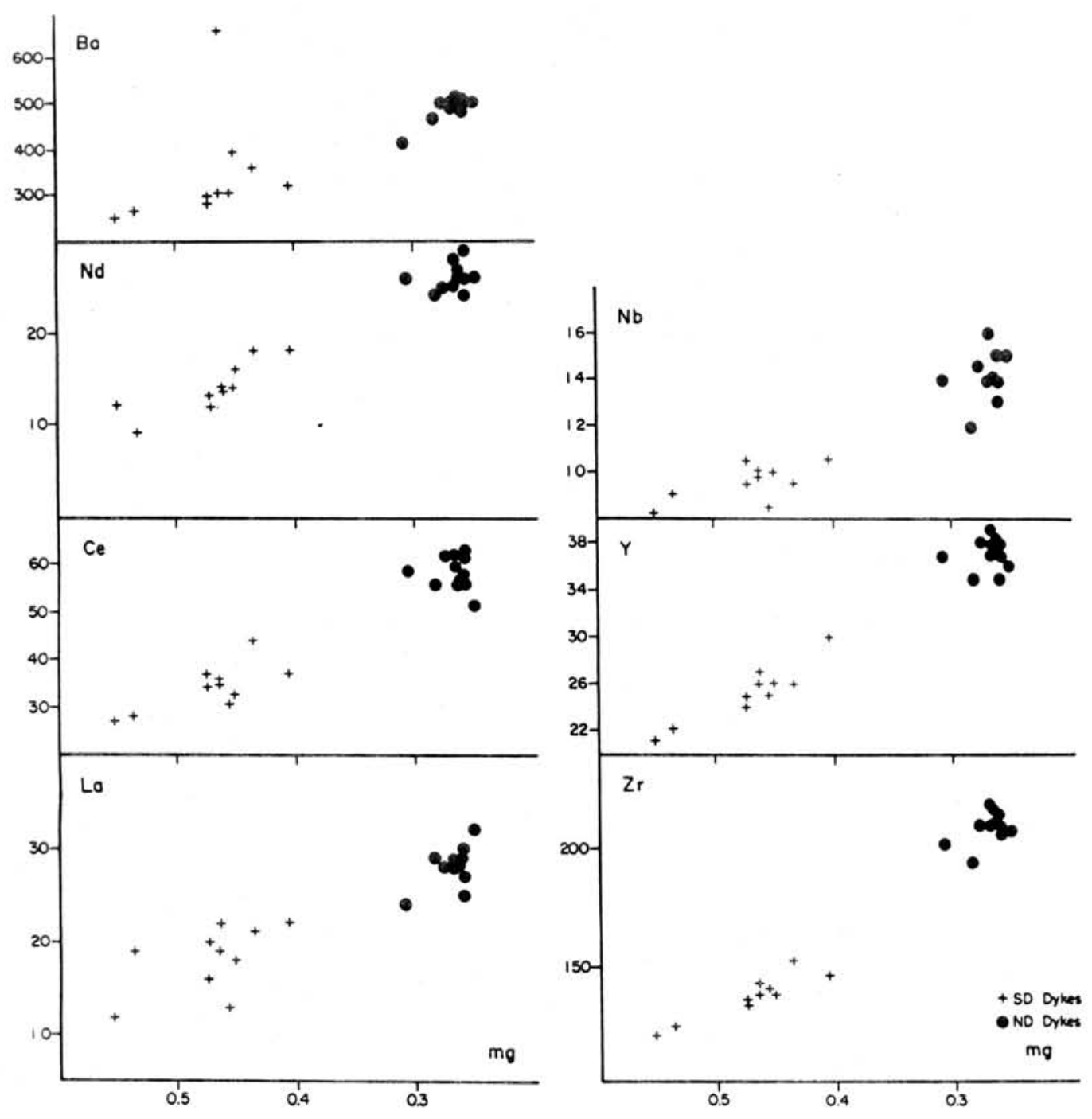

Figure 3 - $\mathrm{mg}$ versus $\mathrm{Ba}, \mathrm{Nd}, \mathrm{Ce}, \mathrm{La}, \mathrm{Nb}, \mathrm{Y}$ and $\mathrm{Zr}$. 

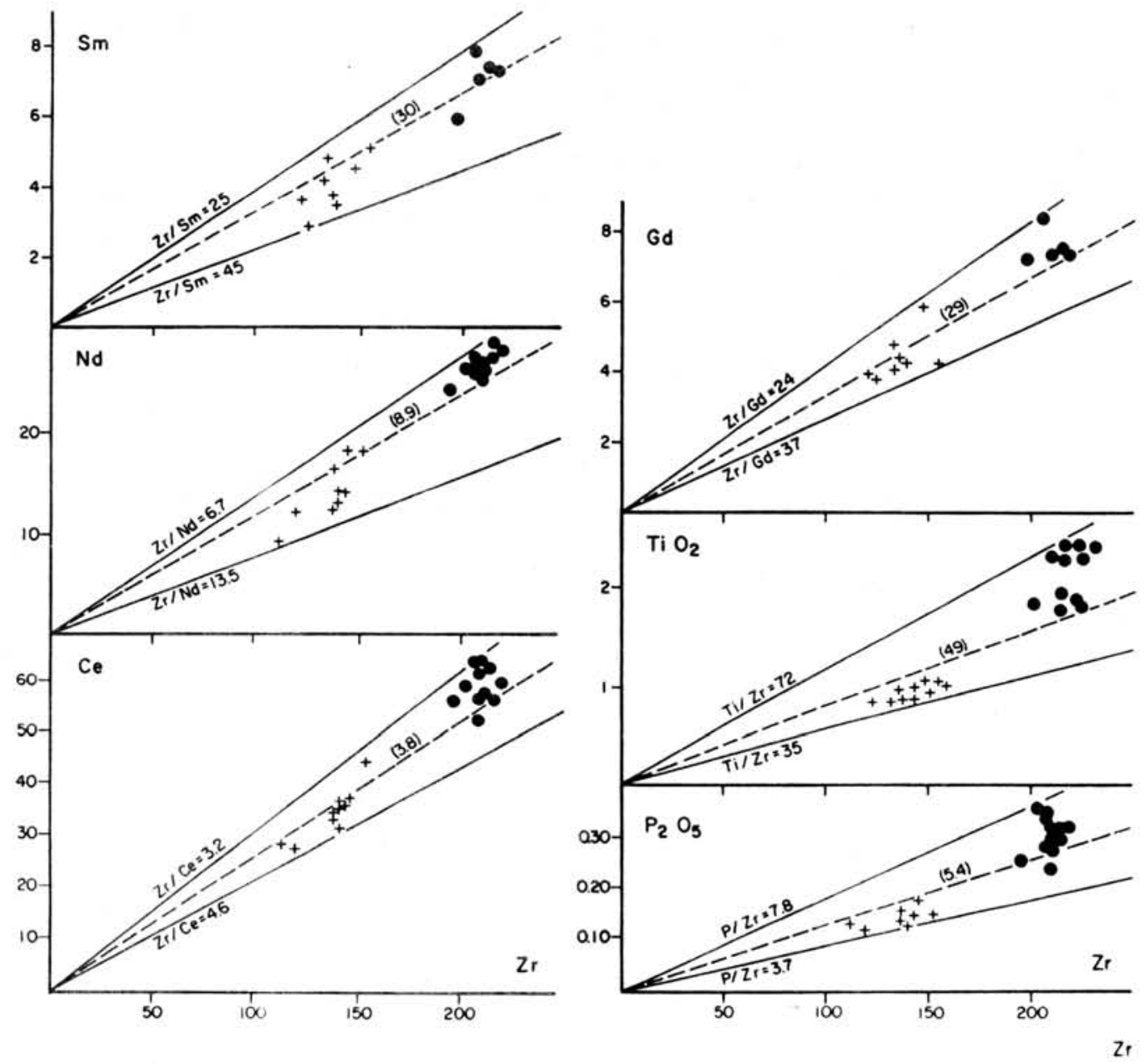

Figure 4 - Incompatible element ratios. 
$\mathrm{A} \mathrm{Rb}-\mathrm{Sr}$ isochron on samples of the dykes indicates an age of $1.86 \pm 0.16 \mathrm{Ga}$ and to an initial ${ }^{87} \mathrm{Sr} /{ }^{86} \mathrm{Sr}$ ratio $\left(R_{\mathrm{o}}\right)$ of 0.7031 (sigma $=0.0012$ ), which plots slightly above the Bulk Earth evolutionary curve (i.e., 0.7024). These data suggest that either the mafic dykes were derived from a slightly enriched mantle source or the parental magma suffered contamination by interaction with crustal material. In the latter case there would have been a contribution of approximately $10 \%$ of crustal material, if the "felsic Archean crust" ( $\mathrm{Rb}=65 \mathrm{ppm}, \mathrm{Sr}=300 \mathrm{ppm}$ ) is assumed to be the country rock. Thus, if crustal contamination occurred, it played a minor role in the genesis of the studied dykes. The first hypothesis, which presumes the existence of a slightly enriched mantle, can be related to "metasomatic" processes responsible for important differences among the ratios of several trace elements ( $\mathrm{P} / \mathrm{Zr}, \mathrm{Ti} / \mathrm{Zr}, \mathrm{Zr} / \mathrm{Ce}, \mathrm{Zr} / \mathrm{Sm}, \mathrm{Zr} / \mathrm{Nd}$ and $\mathrm{Zr} / \mathrm{Gd})$. It is also compatible with the differences in $\mathrm{TiO}_{2}$ contents in the ND and SD swarms.

The frequency distributions of $\mathrm{La} / \mathrm{Nd}$ ratios of the dykes from Uruguay are compared in Fig. 5 with the Mesozoic and Precambrian Brazilian dykes studied by PICCIRILLO et al. (1989). The resulting patterns are very similar to that determined for typical continental basalts and show clear differences with the characteristic diagrams of basalts erupted in island arcs and oceanic islands.

\section{ACKNOWLEDGMENTS}

V.A.V.Girardi, W.Teixeira and A.R.Fragoso-Cesar acknowledge the Brazilian agencies FAPESP, CNPq and FINEP for financial support.

\section{REFERENCES}

BOSSI, J.; CAMPAL, N.; GARAT, I.; PIÑEYRO, D. (1989) First integrated photogeological map of the Precambrian dyke swarm of Uruguai: some geological inferences. Boletim IG-USP, Série Cientifica, 20:57-60.

GOMES RIFAS, C.E. (1988) La edad de los microgabros negros del Proterozoico Medio del Uruguay. In: REUNION GEOLOGICA URUGUAYA, 1., Salta, 1988. Actas. Salto. p.106-107. 

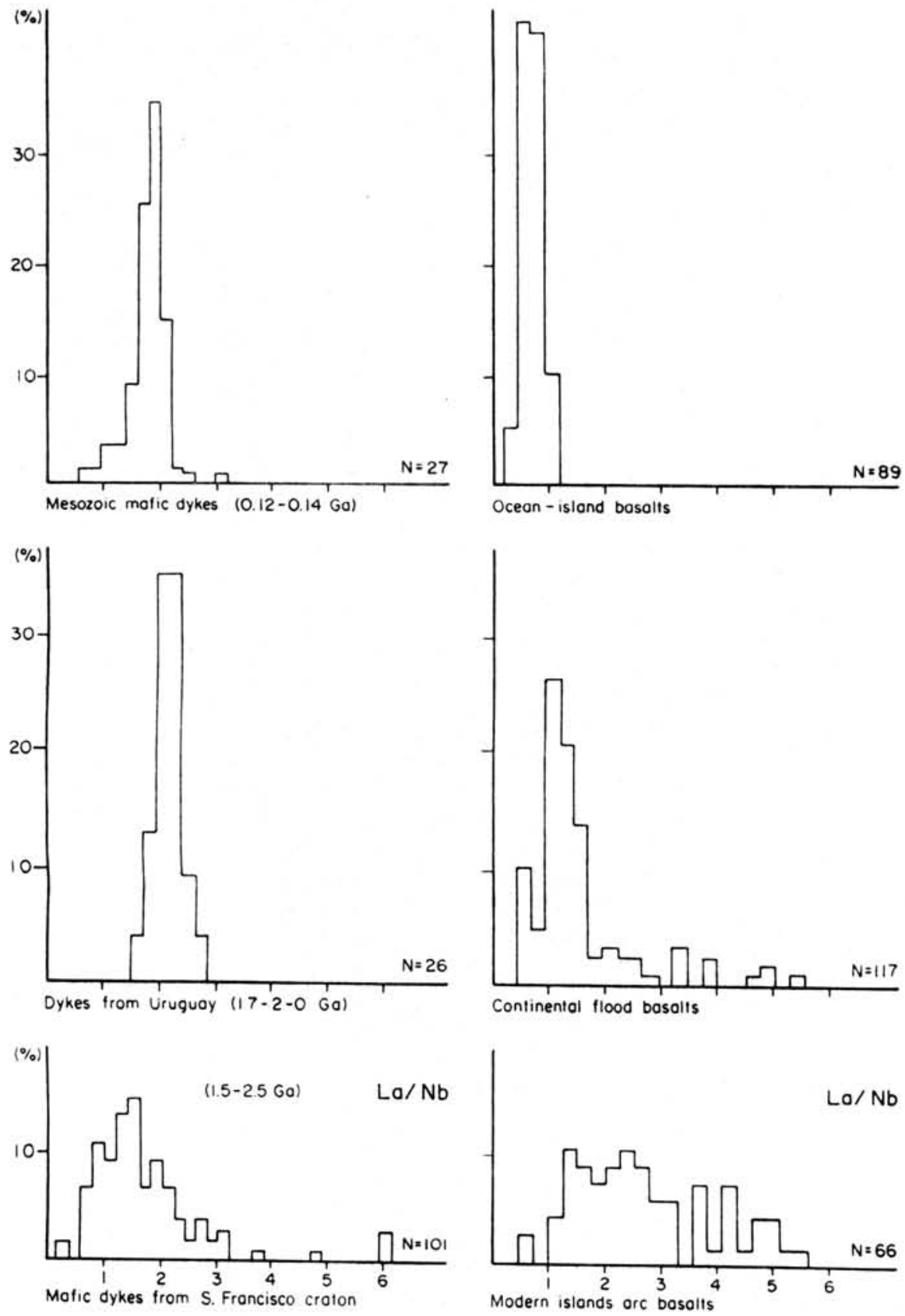

Figure 5 - Frequency distribution of La/Nb ratios of dykes from Brazil and Uruguay compared with basalts from different tectonic settings. $N=$ number of samples. 
PICCIRILLO, E.M.; BELLIENI, G.; MORAES-BRITO, C.; COMIN-CHIARAMONTI, P.; MARTINS, G.; MACEDO, M.H.F.; MELFI, A.J.; PINESE, J.P.P.; TANNER DE OLIVEIRA, M.A.F. (1989) La/Nb variation in Proterozoic and Mesozoic dyke swarms in Brazil. Boletim IG-USP, Série Clentifica, 20:37-40. 